Journal of Social Sciences 6 (4): 510-514, 2010

ISSN 1549-3652

(C) 2010 Science Publications

\title{
Cyberbullying Victimization and Behaviors Among Girls: Applying Research Findings in the Field
}

\author{
Patricia A. Snell and Elizabeth K. Englander \\ Massachusetts Aggression Reduction Center, Bridgewater State College, \\ Bridgewater, MA 02325, Massachusetts, United States
}

\begin{abstract}
Problem statement: Prior research on cyberbullying has been conducted; however specific research on gender differences has yet to be examined. The current study focuses on gender trends, specifically females, in cyberbullying victimization and behaviors. Approach: A survey was given to undergraduate students at Bridgewater State College in an effort to see what gender trends exist in cyberbullying behaviors. A pilot program focused on girls and cyberbullying is also examined in this article. Results: Preliminary results from both the survey and the pilot study have shown gender differences in regards to cyberbullying victimization and behaviors. Results suggest that females are more often involved in cyberbullying activities both as victims and perpetrators. Conclusion: The current study has found evidence of gender trends in regards to females and cyberbullying behaviors. Future research needs to be conducted to further examine the gender trends emerging in cyberbullying related behaviors.
\end{abstract}

Key words: Cyberbullying, bullying behaviors, gender differences, victimization

\section{INTRODUCTION}

Bullying and aggression in schools today have reached epidemic proportions (Nansel et al., 2001). While always in existence, bullying behaviors have increased in frequency and in severity in the past few decades (Olweus, 1993). Although it is often pointed out that bullying "has always existed," the changes in this type of aggression reside not in its existence but in its frequency and quality. Abusive bullying behaviors begin in elementary school, peak during middle school and begin to subside as children progress through their high school years (Feinberg, 2003). Forty-four percent of Massachusetts schools in a 2009 survey characterized the bullying in their school as occurring daily or more often (Englander, 2009).

Types of research included under the "traditional bullying" rubric include physical bullying and emotional bullying. Gender differences, while possibly decreasing, are well established in the research literature. Research on male bullying suggests that boys are more frequently involved in physical bullying (Viljoen et al., 2005). While males usually have physical altercations, females prefer to bully indirectly through relational means. Types of relational bullying or aggression include gossiping or spreading rumors, friendship betrayals, excluding people and other behaviors that manipulate relationships (Raskauskas and Stoltz, 2007; Viljoen et al., 2005).
Because online teenage life is ever-present among First World teenagers, cyberbullying may become-or may already be-the dominant form of bullying behavior among children. A telephone study of 886 US. Internet users age 12-17 (Conducted October to November, 2006) found that one-third (32\%) of all teenagers who use the Internet say they have been targeted for cyberbullying online (Lenhart, 2007). A 2006-2008 survey of 18 and 19 year old college freshman in Massachusetts found that $42 \%$ reported having been "harassed, bullied, stalked, or threatened via instant messaging" (Englander, 2006). Over one-fifth (22\%) of the respondents in that study also admitted being a cyber bully themselves. Over two-thirds (73\%) had seen an insulting, threatening, or degrading profile on a social networking website such as MySpace. A followup MARC survey in 2009 of undergraduate students found that $27 \%$ admitted to cyberbullying and that, $60 \%$ admitted to being victimized online (Englander, 2009). A 2006 poll of 1,000 children conducted by Fight Crime: Invest in Kids, Found cyberbullying frequencies of about 33\%-similar to those found by Pew (Lenhart, 2007). These numbers suggest that cyberbullying (with about 40-60\% admitting victimization) may be more common than traditional bullying (with about $20-24 \%$ admitting victimization).

In the most recent MARC survey (Englander, 2008) most cyberbullying perpetrators attributed their

Correspondence Author: Patricia A. Snell, Massachusetts Aggression Reduction Center, Bridgewater State College, Bridgewater, MA 02325, Massachusetts, United States 
online bullying to either anger (65\%) or "a joke" $(35 \%)$ with "no reason" being a distant third choice. More than two-thirds of students knew a friend who had been victimized online and almost one-fourth (24\%) characterized cyberbullying as either prevalent or very prevalent in their high school. Even if cyberbullying is more prevalent than in-person bullying, the focus of cyberbullying seems to be similar to the focus of bullying: The most common justifications for cyberbullying were the target's appearance and/or who they dated or befriended.

Cyberbullying seems to evoke bullying behaviors among some adolescents who otherwise might not bully. Only $13 \%$ of the college students in MARC's 2007 study (above) expressed the opinion that most cyber bullies "would bully no matter what;" instead, they saw bullying online as an opportunistic crime ("easier because you don't see the person" (69\%), done because "you can do it anonymously" (65\%). More than two-thirds of the respondents $(72 \%)$ characterized cyber bullies as predominantly female-a stark contrast to the traditional view that males are predominant in aggression (Englander, 2008).

While bullying prevention work today benefits from a substantial research literature, cyberbullying by contrast has a much thinner dossier. Cyberbullying research is just beginning to emerge from several research centers in the United States and abroad. Studies involving both males and females using aggregate analyses have been conducted in an effort to see trends in cyberbullying. However, studies with a specific focus on gender differences in cyberbullying are very few in number. This study reports on a study and pilot field program which focus specifically on girls and cyberbullying.

As noted above, a few studies have looked at gender differences in cyberbullying. A handful of research findings suggest that females are more often involved in cyberbullying both as a victim and as a cyber bully (Dehue et al., 2008; Mesch, 2009; Slonje and Smith, 2008; Vandebosch and Van Cleemput, 2008; Jackson et al., 2009; Haque and Khatibi, 2004). The cyberbullying noted among females is consistent with the types of indirect bullying seen between girls in traditional bullying. "Because most cyberbullying is not face-to-face, the gender balance in bullying might be skewed more towards girls than is found for conventional bullying" (Slonje and Smith, 2008). Cyberbullying is an indirect form of aggression which creates a sense of anonymity. The use of text messaging, Emails and instant messaging, makes electronic communications an easy way for rumors to be spread and friendships destroyed. Others have suggested that based on offline bullying preferences, females might be more involved in cyberbullying related activities (Slonje and Smith, 2008).

Girls may also be more involved in cyberbullying as victims. In a study conducted by (Smith et al., 2008) results showed that girls were significantly more likely to be cyber bullied, especially by text messages and phone calls, than boys. This is also true for a study (Mesch, 2009). Results in that study showed that gender was associated with cyberbullying: "Only 39\% of the males were victims, while $61 \%$ of the girls reported being bullied at least once" (Mesch, 2009). In a similar study conducted by (Slonje and Smith, 2008), results showed that "girls were more often victims of cyberbullying and the victims suggested that when known, the bullies were girls as or more often than boys; focus group pupils often guessed that girls would be more involved".

One study supports the theory that girls may be preferentially involved in cyberbullying because it so easily supports relational aggression threats, blackmail, destroying friendships, gossip and rumors. Dehue et al. (2008) surveyed male and female participants on their internet bullying experiences, both as bullies and as victims. Girls reported that when they did cyber bully, they often did this by gossiping or by ignoring someone. In the same study, girls reported being the victim of cyberbullying more often via MSN, hacking, email, name-calling, gossiping and blaming (Dehue et al., 2008).

Another factor that may be related to vulnerability to cyberbullying is the amount of time spent on computers and cell phones for social interactions. One study found that females are online more frequently for socializing purposes, in comparison to males, who go online more frequently to play games (Dowell et al., 2009). In another study conducted by (Juvonen and Gross, 2008) results showed that girls were significantly more likely to be users of email, profile sites, blogs and cell phones in comparison to boys. This more frequent usage may represent more opportunity to become involved in cyberbullying behaviors and victimization. Online activity for social interactions can lead to friend disagreements and fights or perpetuate an ongoing conflict that originated in school.

\section{MATERIALS AND METHODS}

Participants: 213 College students (57 Males and 156 females; primarily freshman) were recruited from the Bridgewater State College psychology research pool. Students who participated in this study received 
participation credit towards the research requirement for the introductory psychology course at the College. Bridgewater State College is a suburban, mid-sized public College located south of Boston, Massachusetts, which primarily draws students from around the State.

Procedure: Participants $(\mathrm{N}=213)$ completed an online survey, composed of 218 questions regarding bullying and cyberbullying victimization and behaviors. Questions pertaining to age, sex, educational background, current living situations and job status where also included in the survey. Subjects were also asked about topics such as their typical daily activities while K-12 students and a few questions about their family life, including their parents' participation in and knowledge about, their online activities. The disproportionate gender distribution is due to (a) the study's being primarily focused on females, with the boys surveyed mainly for comparison purposes and (b) the gender distribution typically found in introductory psychology courses.

\section{RESULTS}

The purpose of this study is to report a small set of preliminary results that directly inform our fieldwork with girls and cyberbullying problems and to describe the fieldwork briefly. More sophisticated statistical analyses will be conducted for future reports. Comparison reports have been conducted on the data collected from the survey questions in an effort to see if any gender differences exist in regards to cyberbullying behaviors. Some gender differences have been noted.

Types of cyberbullying victimization: In a number of items, students were asked to describe which types of cyberbullying victimization they experienced and which types they considered the most common among themselves and their peers. Consistently, use of the internet to spread rumors or lies emerged at the tops of these lists. Stalking online also frequently emerged as a common type of behavior. Girls clearly experienced online rumors and online lies more frequently than boys (Fig. 1 and 2).

In addition to their more frequent victimization by rumors and lies, girls reported to us more often that they had problems on social networking sites (usually Face book); they more often reported problems such as harassment and threats on their Wall and lies or false stories on their Wall. Boys and girls both reported at about the same frequency $(9-10 \%)$ that someone had created a fake, derogatory profile about them (Fig. 3).

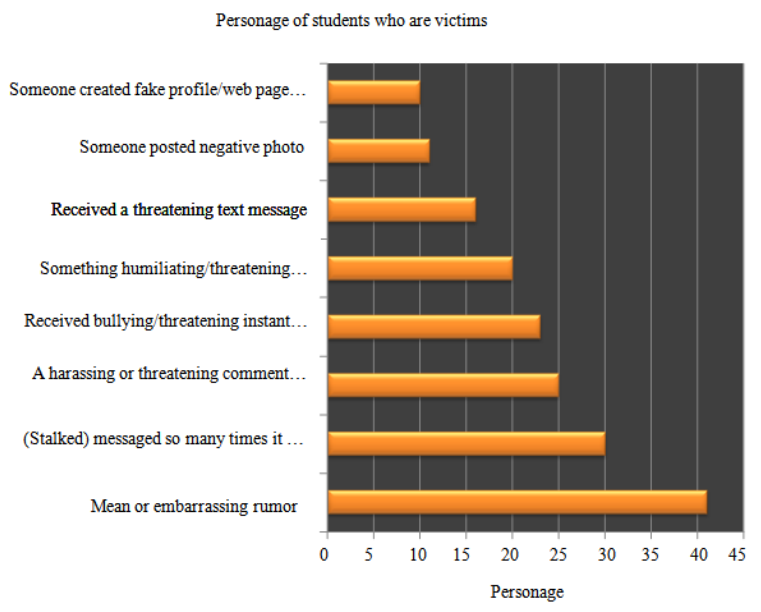

Fig. 1: Rumors emerged as most common form of victimization

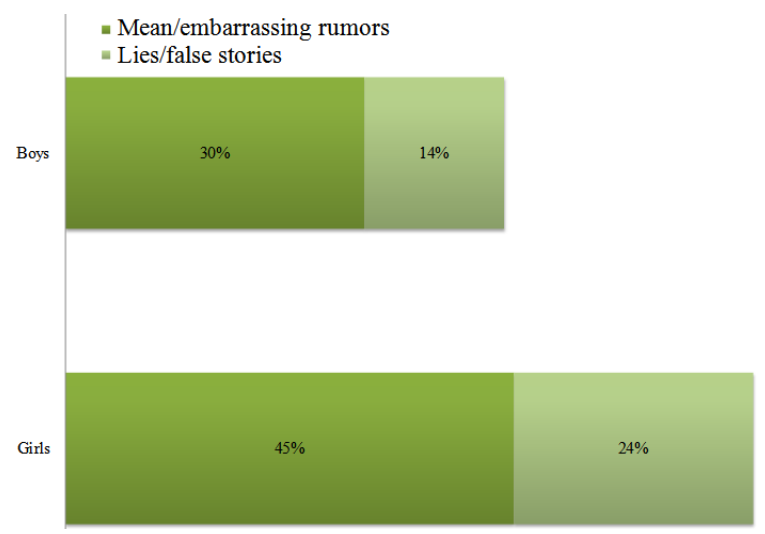

Fig. 2: Girls were more often victimized by Rumors and Lies online

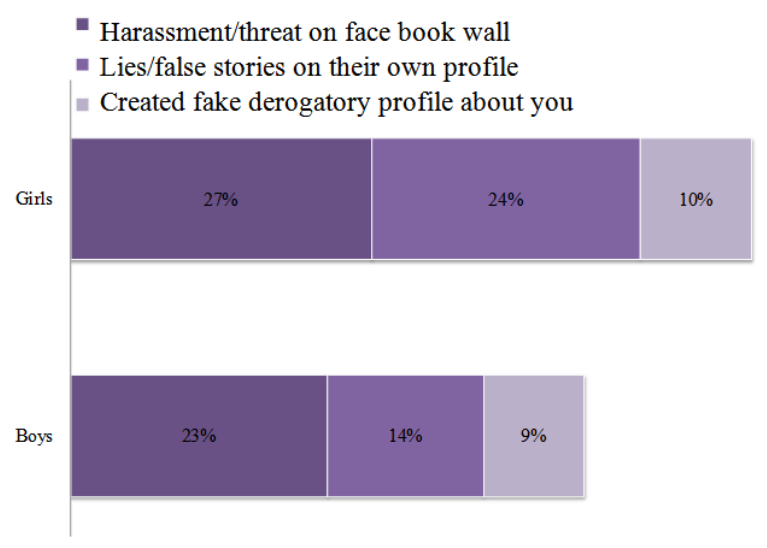

Fig. 3: Face book problems, girls Vs boys 


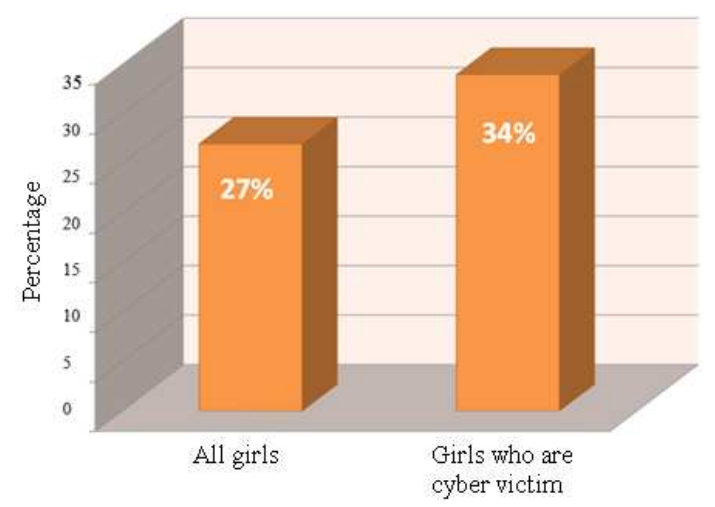

Fig. 4: Percentage of girls who sext because they were coerced

A final problem which we address directly in our fieldwork with girls and their parents involves "sexting," which is the sending or posting of nude or semi-nude "inappropriate" pictures. Willard (In Press) has noted that there can theoretically be both developmentally normal motives for sexting (e.g., sexual curiosity) and more deviant motives (e.g., abuse, bullying or blackmail). We asked our subjects if they had ever been coerced, blackmailed, or threatened into sending a nude photo of themselves and surprisingly, fully $27 \%$ of girls who had sexting answered affirmatively. This important finding suggests that a substantial minority of girls (and possibly boys) are being bullied or threatened into sexting and that they apparently lack the knowledge or wherewithal to resist or report this type of serious sexual harassment. Warning students that sexting is a serious crime may in fact backfire, as victims may become aware that if they report their victimization, they could possibly be prosecuted for distribution of child pornography. Figure 4 show the "sexting under coercion" distributions.

Although these are only preliminary results, many gender trends are emerging that are similar to previous research findings. Females are spending more time texting and online with friends. The situations that are occurring seem to be involving friends or ex-friends involved in relational or indirect aggression (rumors, blackmail and destroyed friendships). These behaviors are typical of females and their indirect bullying styles.

Pilot fieldwork: Goals of the project: The Massachusetts Aggression Reduction Center (MARC), located at Bridgewater State College, has (in addition to its research activities) been educating students, faculty, parents and law enforcement on bullying and cyberbullying related issues for over five years. Representatives from MARC travel all over the Commonwealth to promote student and parent based programs about bullying and cyberbullying awareness, as well as violence prevention. A pilot project in five Massachusetts schools is being conducted in an effort to see what type of impact these programs are making as well as obtaining feedback from these schools and parents. The schools involved in this pilot study are all suburban high schools and middle schools located in southeastern Massachusetts. The pilot programs in these five schools consist of educational and interactive girls-only assemblies about cyberbullying and educational evening presentations for the parents of girls. The pilot program was funded by the Women's Fund from the Southeastern Community Foundation of Massachusetts.

Student programs: Student programs include assemblies which incorporate the different types of bullies and how to deal with related situations as well as internet safety and cyberbullying awareness. These assemblies are interactive (students are not passive participants, but are continually required to contribute their ideas and opinions) and focus on some of the research highlights: The problems of rumors and lies online; texting and Face book problems and sexting and coercion. The assembly approaches these topics from a realistic standpoint (e.g., the female facilitator always acknowledges that it can be fun and interesting to gossip about people and spread rumors, but that gossip comes at a price, too). The female facilitator is deliberately non-professional and the model is that of a high-status peer, rather than an adult figure; to achieve this, graduate students in MARC are trained to deliver the assemblies.

Parent Programs: Parent based programs provide information regarding current online activities of youth today and internet safety, including cyberbullying issues. These programs are focused on providing parents with information on how to work with their children and schools in bullying or cyberbullying situations. Similar to the student programs, the parent based programs are directed towards spreading awareness to parents about current issues that their children and adolescents are potentially dealing with.

\section{DISCUSSION}

It is notable that when the funding for this pilot program was announced, the five available slots were filled up within one hour-and the clamor for these programs has not ceased since then. Educators in the field see the problem of girls and their cyberbullying behaviors and victimizations as critically important. Clearly, further research needs to be conducted on both 
bullying and cyberbullying trends in an effort to improve anti-bullying/cyberbullying programs such as MARC. The current study focused on only a few of the findings of this study in search of more understanding as to why cyberbullying occurs so frequently and who is involved most often in these cases. By continuing research efforts, new information will be obtained and can be used to spread awareness about the problems that children and adolescents are facing today. By understanding what these problems are future antibullying/cyberbullying programs will be more effective at helping students and parents. It is still not clear as to why children and adolescents engage in bullying and cyberbullying behaviors. Continued research in this area may help clarify this question.

\section{CONCLUSION}

Results from previous research as well as the preliminary results found in this study suggest that females are more often involved in cyberbullying related behaviors both as victims and perpetrators. The amount of time spent on the internet and cell phones may be correlated with the frequency of these cyberbullying behaviors. The relational aggression styles typical of females are also suggested to have a correlation with these bullying styles. Research needs to continue to be conducted on gender trends in cyberbullying. Training and education for students and faculty will help spread awareness surrounding cyberbullying behaviors.

\section{REFERENCES}

Dehue, F., C. Bolman and T. Vollink, 2008. Cyberbullying: Youngsters' experiences and parental perception. Cyberpsychol. Behav., 11: 217-223. PMID: 18422417

Dowell, E.B., A.W. Burgess and D.J. Cavanaugh, 2009. Clustering of internet risk behaviors in a middle school student population. J. School Health, 79: 547-553. PMID: 19840232

Englander, E.K., 2006. Understanding Violence. 3rd Edn., Lawrence Erlbaum and Associates, Mahwah, New Jersey, ISBN: 10: 0805860908, pp: 256.

Englander, E., 2008. Cyberbullying and bullying in Massachusetts: frequency and motivations. Massachusetts Aggression Reduction Center. http://webhost.bridgew.edu/marc/MARC\%20findin gs\%20summary\%202008.pdf

Englander, E., 2009. SNAPSHOT: Massachusetts statistics on frequency of bullying and cyberbullying (2008-09). Massachusetts Aggression Reduction Center. http://webhost.bridgew.edu/marc/SNAPSHOT\%20 stats\%2008 09.pdf
Haque, A. and A. Khatibi, 2004. Children perception on TV advertisement: The impact of age, gender and parental influence. Am. J. Applied Sci., 1: 149-154. DOI: $10.3844 / .2004 .149 .154$

Jackson, L.A., Y. Zhao, E.A. Witt, H.E. Fitzgerald and A.V. von Eye et al., 2009. Self-concept, selfesteem, gender, race and information technology use. Cyberpsychol. Behav., 12: 437-440. PMID: 19514819

Juvonen, J. and E.F. Gross, 2008. Extending the school grounds?--bullying experiences in cyberspace. J. Schools Health, 78: 496-505. PMID: 18786042

Lenhart, A., 2007. Cyberbullying and online teens. Pew Internet and American Life Project. http://www.pewinternet.org/ /media/Files/Reports/ 2007/PIP\%20Cyberbullying\%20Memo.pdf.pdf

Mesch, G.S., 2009. Parental mediation, online activities and cyberbullying. Cyberpsychol. Behav., 12: 387-393. PMID: 19630583

Nansel, T.R., M. Overpeck, R.S. Pilla, W.J. Ruan and B. Simons-Morton et al., 2001. Bullying behaviors among US youth: Prevalence and association with psychosocial adjustment. J. Am. Med. Assoc., 285: 2094-2100. PMID: 11311098

Feinberg, T., 2003. Bullying prevention and intervention. Principle Leadership Mag., 4: 1-1. http://www.nasponline.org/resources/principals/nas sp_bullying.aspx

Olweus, D., 1993. Bullying at School: What We Know and What We Can Do. 1st Edn., Wiley-Blackwell, Cambridge, MA., ISBN: 10: 0631192417, pp: 152.

Raskauskas, J. and A.D. Stoltz, 2007. Involvement in traditional and electronic bullying among adolescents. Dev. Psychol., 43: 564-575. PMID: 17484571

Slonje, R. and P.K. Smith, 2008. Cyberbullying: Another main type of bullying? Scand. J. Psychol., 49: 147-154. PMID: 18352984

Smith, P.K., J. Mahdavi, M. Carvalho, S. Fisher and S. Russell et al., 2008. Cyberbullying: Its nature and impact in secondary school pupils. J. Child Psychol. Psychiatry, 49: 376-385. PMID: 18363945

Vandebosch, H. and K. Van Cleemput, 2008. Defining cyberbullying: A qualitative research into the perceptions of youngsters. Cyberpsychol. Behav., 11: 499-503. DOI: 10.1089/cpb.2007.0042

Viljoen, J.L., M.L O’Neill and A. Sidhu, 2005. Bullying behaviors in female and male adolescent offenders: Prevalence, types and association with psychosocial adjustment. Aggress. Behav., 31: 521-536. DOI: 10.1002/ab.20036 